Article

\title{
Phytoremediation of Aluminum and Iron from Industrial Wastewater Using Ipomoea aquatica and Centella asiatica
}

\author{
Marlia Mohd Hanafiah ${ }^{1,2}{ }^{*}$, Muhamad F. Zainuddin ${ }^{1}$, Nurul Umairah Mohd Nizam ${ }^{1}$, \\ Azhar Abdul Halim ${ }^{1}$ and Akhtar Rasool ${ }^{3,4}{ }^{\mathbb{D}}$ \\ 1 Department of Earth Sciences and Environment, Faculty of Science and Technology, Universiti Kebangsaan \\ Malaysia, UKM Bangi 43600, Selangor Darul Ehsan, Malaysia; marlia.mhanafiah@gmail.com (M.F.Z.); \\ umairahnizam@yahoo.com (N.U.M.N.); azharhalim@ukm.edu.my (A.A.H.) \\ 2 Centre for Tropical Climate Change System, Institute of Climate Change, Universiti Kebangsaan Malaysia, \\ UKM Bangi 43600, Selangor Darul Ehsan, Malaysia \\ 3 Toxicology Unit, Pharmacology and Toxicology Division, CSIR-Indian Institute of Chemical Technology, \\ Hyderabad 500007, India; Akhtarrasool01@gmail.com \\ 4 Department of Environmental Sciences, Osmania University, Hyderabad 500007, India \\ * Correspondence: mhmarlia@ukm.edu.my; Tel.: +603-89215865
}

Received: 9 April 2020; Accepted: 26 April 2020; Published: 28 April 2020

check for updates

\begin{abstract}
Heavy metals accumulation from industrial wastewater even at low concentrations can cause long term cumulative health effects. To overcome this problem, phytoremediation is an alternative method to treat industrial wastewater. In this study, Ipomoea aquatica and Centella asiatica were used as phytoremediation plants for removing aluminum ( $\mathrm{Al})$ and iron $(\mathrm{Fe})$ from industrial wastewater. The results showed that the regression value $\left(R^{2}\right)$ for all metal concentrations $(\mathrm{mg} / \mathrm{L})$ over treatment day is positive and similar to $R^{2}=1$. This result indicated that the metal concentration exhibits a good relationship for reflecting the decrease in the metal concentration with the proportion of treatment day. It was found that I. aquatica accumulates higher $\mathrm{Al}$ and Fe contents than C. asiatica. The translocation factor of both plants was found to be greater than 1, implying that both plants can accumulate and extract heavy metals from industrial wastewater.
\end{abstract}

Keywords: phytoremediation; industrial wastewater; Ipomoea aquatica; Centella asiatica; Malaysia

\section{Introduction}

The rapid increase in industrial activities and the increase in the human population have resulted in the increase in water, air, and soil pollution [1,2]. Hence, some efforts to conserve and preserve the environment are required. Untreated effluents resulting from industrial activities, which contain a high content of heavy metals, can pollute water sources [3,4]. Morais et al. [5] and Shuhaimi et al. [6] have independently reported that heavy metals are the main environmental pollutants, and refining, smelting, and plating intermediate industries represent one of the contributors.

In general, industrial wastewater is often treated by a combination of physical, chemical, and biological treatment methods. Such a combined treatment can guarantee the maximum elimination of various pollutants, such as organic and inorganic pollutants. However, the treatment methods are expensive, which is not feasible in the industrial sector. A number of treatment methods have been developed to remove heavy metals from wastewater [7-10]. Phytoremediation is an alternative technique that can be employed to treat industrial wastewater for reducing water pollution [11].

As a more cost-effective, environmentally friendly technology, phytoremediation is a nature-based treatment, particularly employed for treating contaminated soil, groundwater, and surface water [12]. 
Phytoremediation refers to technologies that use various plants to stabilize, remove, or destroy environmental contaminants. Basically, phytoremediation functions via the ability of plants to translocate, accumulate, and restore or degrade pollutants [13,14]. Ahmadpour et al. [15] and Favas et al. [16] have independently reported that phytoremediation is defined as green-plant engineering that can destroy, restore, and reduce heavy metals and trace elements from the environment.

Although several studies on phytoremediation have been performed in Malaysia, further study is still required to enhance the understanding of this alternative technology. Research on the variety of plants, type of medium, pollutant specification, and analysis costs needs to be conducted before implementation to ensure the maximum outcomes. Souza et al. [17] reported that heavy-metal extraction is affected by the ability of plants to accumulate heavy metals, soil concentration and physicochemical characteristics, and the strength of the metallic bond in soil.

In Malaysia, Environmental Quality (Sewage and Industrial Effluents) Regulation and Drinking Water Quality Standards have been adopted by water regulatory bodies. Wastewater and effluent discharge must satisfy the prescribed criteria before its release to water sources. Therefore, phytoremediation for wastewater treatment is crucial as it can accumulate heavy metals from contaminated water [18,19]. Rahman et al. [20] and Karami and Shamsuddin [21] have independently reported that phytoremediation plants can accumulate heavy metals from contaminated soils. Chai et al. [7] reported that several plant species are suitable for use as pollutant removal agents. Yap et al. [14] have used Centella asiatica for the removal of heavy metals from soil samples, while Majid et al. [22] have examined the ability of Acacia mangium for the removal of heavy metals from sewage sludge. Hibiscus cannabinus has been used to remove $\mathrm{Pb}$ from contaminated soil [23], while Amaranthus paniculatus and Brassica juncea have been used by Rahman et al. [20] to treat Pb-and Cu-contaminated soil.

Choo et al. [24] have used Nymphaea spontanea to remove $\mathrm{Cu}$ from plating industrial effluents. Besides, Syuhaida et al. [25] have used N. oleracea and E. crassipes to treat wastewater contaminated with $\mathrm{Pb}, \mathrm{Cd}$, and $\mathrm{Cu}$. Their results revealed that $N$. oleracea is more efficient than E. crassipes for accumulating the selected heavy metals. Pistia stratiotes and E. crassipes have been used to treat aquaculture wastewater from a fish pond in Semanggol, Perak [26]. Lim et al. [27] have used Chlorella vulgaris to treat wastewater released from the textile industry. Ashraf et al. [28] have used several plant species such as Phragmites australis, Imperata cylindrica, Cyperus rotundus, Nelumbo nucifera, and Pteris vittata to remove heavy metals from tin ore remnants in Bestari Jaya, Selangor.

In this study, the effectiveness of Ipomoea aquatica and C. asiatica for the extraction of aluminum (Al) and iron (Fe) from pulp and paper industrial effluents was investigated, and the translocation factors (TFs) of $\mathrm{Al}$ and Fe by I. aquatica and C. asiatica were compared. I. aquatica and C. asiatica were selected as phytoremediation plants due to their rapid growth rates and low management costs $[29,30]$. This was consistent with the phytoremediation concept, which affords a more cost-effective wastewater treatment technology. Hence, this phytoremediation biotechnology method can be applied for wastewater treatment to reduce water pollution, and such efforts can certainly contribute significantly towards sustainable development.

\section{Materials and Methods}

The samples used herein were industrial wastewater from a paper mill that was collected at Cheng Industrial, Malacca, with coordinates of $2^{\circ} 14^{\prime} 48.7^{\prime \prime} \mathrm{U} 102^{\circ} 13^{\prime} 50.4^{\prime \prime} \mathrm{T}$.

\subsection{Preparation of Phytoremediation Plants}

This study was conducted in a hydroponic system, where the hydroponic method was suitable for aquatic and semi-aquatic plants. Besides, this system was a cost-effective system, with space savings, and required minimal supervision, in addition, the plants grew more rapidly as they did not have to work hard to obtain nutrients. The nitrogen, phosphorus, and potassium (N:P:K) (7:7:7) solutions were used to replace the Hoagland solution to provide nutrient essentials for plant growth, as has been 
reported by Syuhaida et al. [25]. Seedlings were collected from a selected waterbody at Universiti Kebangsaan Malaysia (UKM), Bangi, Selangor. The seedlings were washed and soaked in distilled water, followed by sowing on cotton wool. Cotton wool was used as a platform to float plants in the tank, and this method also was applied for wastewater treatment in a synthetic reservoir. Figure 1 shows two reservoirs with a dimension of $1 \mathrm{~m} \times 0.5 \mathrm{~m} \times 0.30 \mathrm{~m}$, which were used to grow I. aquatica and C. asiatica. Thirty-gram samples of each plant were placed in the reservoir filled with $6 \mathrm{~L}$ of wastewater for the simulated extraction of heavy metals.

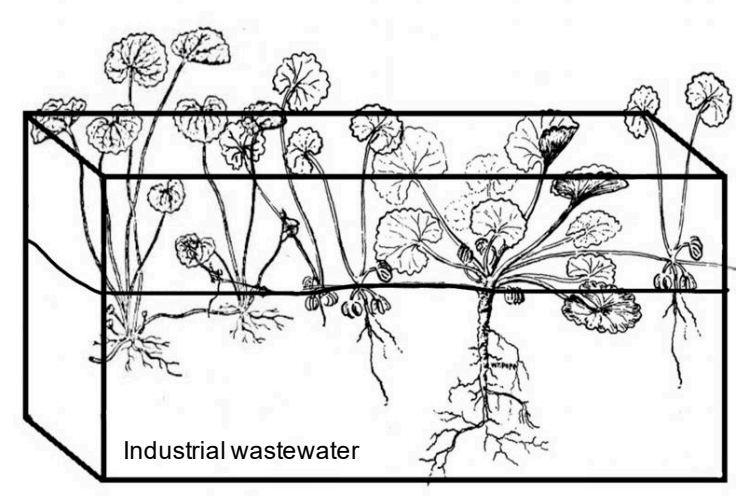

Centella asiatica

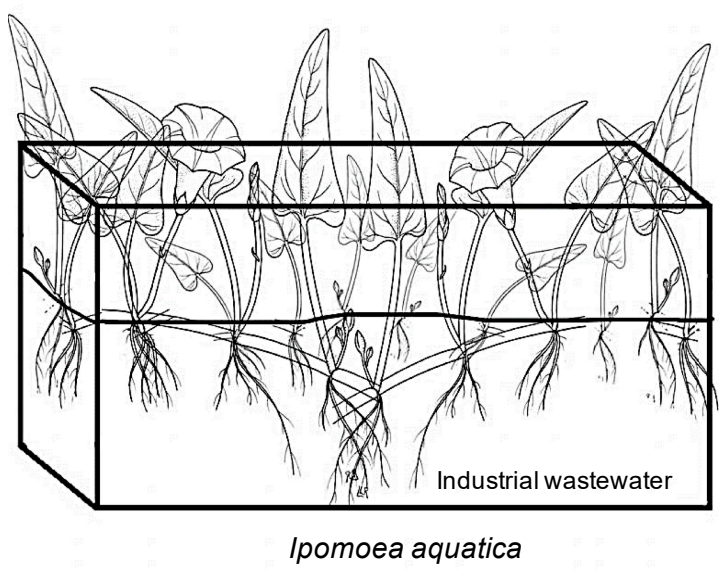

Ipomoea aquatica

Figure 1. Schematic of the aquatic plant germination in a reservoir.

This section may be divided by subheadings. It should provide a concise and precise description of the experimental results, their interpretation as well as the experimental conclusions that can be drawn.

The growth of seedlings took about 20 days in an open environment to ensure optimum growth. The samples were subsequently transferred into a secondary reservoir filled with wastewater. Next, the samples were subjected to the selected treatment at $24{ }^{\circ} \mathrm{C}$ for 10 days, as has been reported by Ton et al. [31]. At this stage, the water quality and plant conditions were monitored and recorded. A total of 48 samples for heavy metal extraction were obtained, including 12 samples of water for the determination of the heavy metal content in water after the treatment. The plants were harvested, and the water was analyzed at time intervals of $0,2,4,6,8,10$ days after exposure for 10 days, as has been reported by Ladislas et al. [32].

\subsection{Harvesting and Sample Preparation}

In this study, the plants in each reservoir were harvested according to the specified time. Then, the plants were rinsed with tap water, followed by distilled water, to wash any remaining dirt and heavy metal residue from the shoots and roots, followed by drying on a filter paper. Figure 2 shows the harvested and separated plants. The wet sample weight was determined on a digital weighing scale, and the reading was recorded. The plants were cut into three parts: stems, roots, and leaves. Then, the samples were dried in an oven at $70-85^{\circ} \mathrm{C}$ until a constant dry sample weight was obtained. The samples were dried for 2 days to achieve constant weight, and the reading was recorded. The samples were crushed and ground into a fine paste according to the roots, stems, and leaves by using a mortar and pestle. The samples were subjected to hot plate acid digestion.

\subsection{Hot Plate Acid Digestion and Atomic Absorption Spectrometry}

First, $1 \mathrm{~g}$ of sample was added into a porcelain dish and dried in a furnace at $80^{\circ} \mathrm{C}$. After cooling, the samples were digested in $5 \mathrm{~mL}$ of a $10 \%$ hydrochloric acid $(\mathrm{HCl})$ solution. Next, the porcelain dish was placed on the hot plate, and samples were heated to obtain a clear solution. Then, $10 \mathrm{~mL}$ of $20 \%$ nitric acid $\left(\mathrm{HNO}_{3}\right)$ was added, and the samples were heated at $100{ }^{\circ} \mathrm{C}$ for $1 \mathrm{~h}$. Then, the digested solution was cooled to room temperature and filtered by using a $0.45-\mu \mathrm{m}$ cellulose filter 
paper. The filtered samples were purified with Millipore water to obtain a concentrated solution of $50 \mathrm{~mL}$. The samples were then analyzed by atomic absorption spectrometry (AAS, AA-6800 Shimadzu, Japan). AAS was employed to determine the heavy-metal concentration of both plants as follows (Equation (1)):

$$
\text { Heavy-metal concentration }\left(\frac{\mathrm{mg}}{\mathrm{kg}}\right)=\frac{\left[A_{m}\left(\frac{\mathrm{mg}}{\mathrm{L}}\right) \times B_{e}(\mathrm{~L})\right]}{C_{a}(\mathrm{~kg})}
$$

$A_{m}=$ The total heavy-metal concentration of $\mathrm{Fe}$ and $\mathrm{Al}$ in plant $(\mathrm{mg} / \mathrm{L})$

$B_{e}=$ Volume of extraction $(\mathrm{L})$

$C_{a}=$ The plant mass $(\mathrm{kg})$

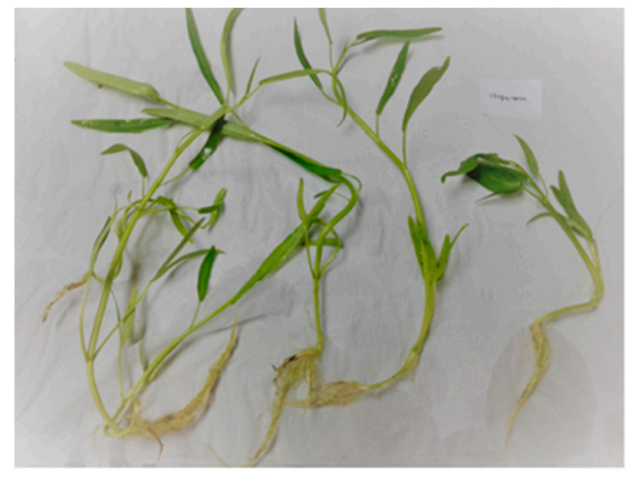

(a)
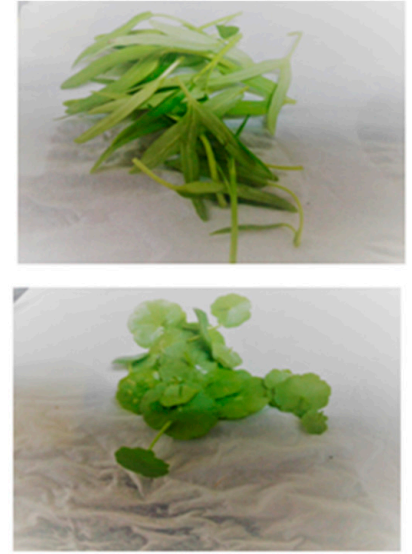

(c)
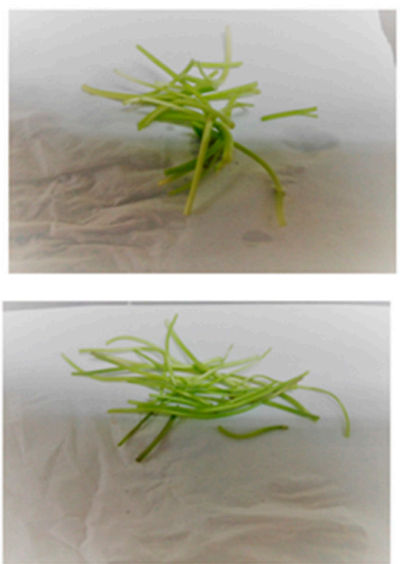

(d)

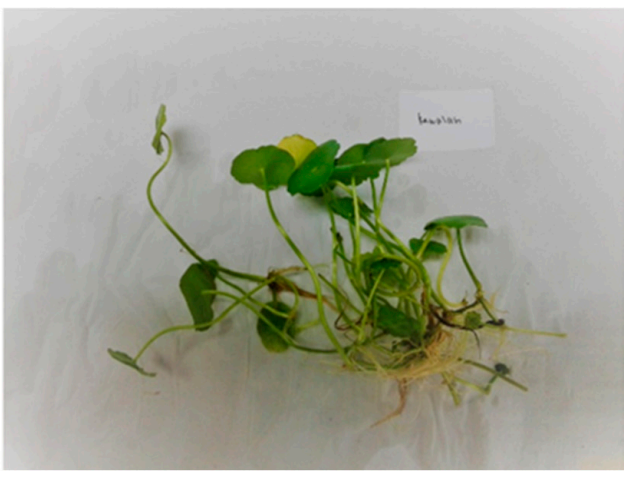

(b)
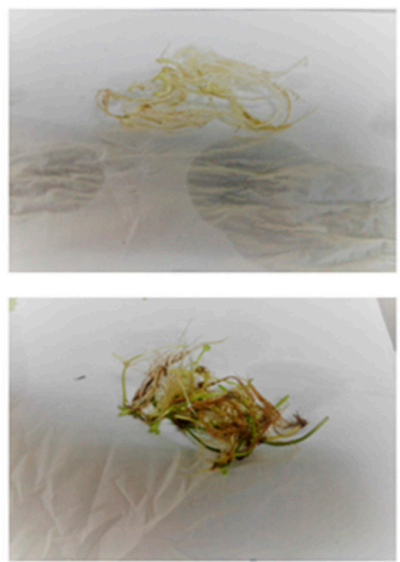

(e)

Figure 2. Harvesting process of (a) Ipomoea aquatica and (b) Centella asiatica, and the separation of; (c) leaves, (d) stems, and (e) roots of Ipomoea aquatica and Centella asiatica.

The extracted heavy metals were analyzed by AAS by the manual injection method. The accuracy of AAS measurements was verified by using a prepared solution and blank according to each heavy metal group. Validation was performed by calibration using a blank. A calibration curve was obtained, reflecting the standards of the heavy metal solution group.

\subsection{Translocation Factor and Accumulated Heavy Metal Amount}

$\mathrm{TF}$ is a ratio of the ability of plants to translocate heavy metals from roots through shoots [33]. $\mathrm{TF}<1$ indicates that heavy metals are accumulated in the roots and vice versa. TF is expressed as follows (Equation (2)):

$$
\mathrm{TF}=\frac{\text { Heavy-metal concentration of stems }(\mathrm{mg} / \mathrm{kg})}{\text { Heavy-metal concentration of roots }(\mathrm{mg} / \mathrm{kg})}
$$


The amount of heavy metals accumulated in plants was determined from the changes in shoots, stems, and roots, which was measured according to the biomass that can be harvested under controlled conditions [32].

\section{Statistical Analysis}

Data were collected and sorted by using IBM SPSS Statistics version 22 software. ANOVA test was conducted to measure the difference in the amount of the heavy metals accumulated in the leaves, stems, and roots from day 0 until day 10 of treatment. Analysis was also conducted to compare changes in the heavy metal accumulation of the leaves, stems, and roots and the effect of the selected plant species on the heavy metal content of water.

\section{Quality Control}

All of the apparatuses used in this study were soaked overnight in a $5 \% \mathrm{HNO}_{3}$ solution, followed by rinsing with distilled water and drying before use. For each measurement, the reading was measured three times to obtain an average value. For the heavy-metal concentration analysis, $15 \mathrm{~mL}$ of each sample solution was added into a vial for flame atomic absorption spectroscopy analysis. The amount of the absorbed plants was analyzed on an AAS (AA-6800 Shimadzu, Japan). The $\mathrm{HNO}_{3}$ solution was used as a blank for the plant sample, which was digested without additional plant materials. The samples were measured in triplicate for each injection by AAS, and the analysis was conducted for every $2-3$ samples.

\section{Results and Discussion}

\subsection{Initial Characteristics of Wastewater}

Wastewater was collected from the paper mill at the effluent channel, which is the final channel before being discharged into the waterbody. The in-situ parameters were recorded by using a YSI multiprobe, whereas other physico-chemical analyses were determined in the laboratory. Then, $1 \mathrm{~L}$ of the wastewater sample was collected and analyzed by inductively coupled plasma mass spectrometry for the determination of the heavy metal content. Results indicated that the heavy metal content is in compliance with the industrial effluent discharge standards as stated in the Environmental Quality (Sewage and Industrial Effluents) Regulation. Table 1 summarizes the results obtained from the analysis of the physico-chemical and heavy metal contents. According to the results obtained herein, $\mathrm{Al}$ and $\mathrm{Fe}$ were selected for the simulation of wastewater remediation to examine the ability of the selected aquatic plants to extract heavy metals. Then, wastewater was treated by using $30 \mathrm{~g}$ of $\mathrm{I}$. aquatica and C. asiatica in a 6-L reservoir in the open air for 10 days.

\subsection{Wastewater Treatment}

\subsubsection{Ipomoea Aquatica}

Figure 3 shows readings for the $\mathrm{Al}$ content accumulated by I. aquatica for 10 days of treatment. Readings recorded on day $0,2,4,6,8$, and 10 were $~ 0.30,0.13,0.12,0.10,0.08$, and $0.04 \mathrm{mg} / \mathrm{L}$, respectively. On the final day of the treatment, the heavy-metal concentration of the wastewater decreased up to $87 \%$. A significant drop was recorded on the second day of treatment, with $\sim 57 \%$. Figure 3 also shows readings for the Fe content for 10 days of treatment. Readings recorded on day $0,2,4,6,8$, and 10 were $\sim 1.09,0.87,0.86,0.8,0.81$, and $0.68 \mathrm{mg} / \mathrm{L}$ respectively. The heavy-metal concentration decreased by $\sim 38 \%$ on the final day of treatment. A significant drop was recorded on the second day of treatment, which was $\sim 20 \%$. 
Table 1. Analysis of the heavy metal content from industrial wastewater.

\begin{tabular}{|c|c|c|c|}
\hline \multirow{2}{*}{ Parameter } & \multirow{2}{*}{ Industrial Wastewater } & \multicolumn{2}{|c|}{ Department of Environment (DOE) (2009) } \\
\hline & & Standard A & Standard B \\
\hline $\mathrm{pH}$ & 7.86 & $6.0-9.0$ & $5.5-9.0$ \\
\hline Temperature $\left({ }^{\circ} \mathrm{C}\right)$ & 31.0 & 40 & 40 \\
\hline Turbidity (NTU) & 20.07 & - & - \\
\hline Total Dissolved Solid (mg/L) & 1132 & - & - \\
\hline Conductivity ( $\mu \mathrm{s})$ & 1613 & - & - \\
\hline Fluoride $\left(\mathrm{F}^{-}\right)$ & 0.8 & 2.0 & 5.0 \\
\hline Nitrate $(\mathrm{mg} / \mathrm{L})$ & 41.52 & - & - \\
\hline Chemical Oxygen Demand (mg/L) & 40 & - & - \\
\hline Biological Oxygen Demand (mg/L) & 5.6 & - & - \\
\hline Hardness (mg/L) & 829 & - & - \\
\hline Element & $\begin{array}{c}\text { Heavy Metals } \\
\text { Concentration }(\mathrm{mg} / \mathrm{L})\end{array}$ & Department of En & DOE) (2009) $(\mathrm{mg} / \mathrm{L})$ \\
\hline Aluminum & 0.30 & 10 & 15 \\
\hline Barium & 0.12 & 1.0 & 2.0 \\
\hline Calcium & 136.84 & - & - \\
\hline Iron & 1.09 & 1.0 & 5.0 \\
\hline Potassium & 12.58 & - & - \\
\hline Lithium & 0.02 & - & - \\
\hline Magnesium & 11.02 & - & - \\
\hline Manganese & 0.07 & 0.20 & 1.0 \\
\hline Nickel & 0.01 & 0.20 & 1.0 \\
\hline Rubidium & 0.03 & - & - \\
\hline Strontium & 0.35 & - & - \\
\hline Zinc & 0.07 & 2.0 & 2.0 \\
\hline
\end{tabular}

* not detected, elements: Arsenic, Beryllium, Bismuth, Cadmium, Cobalt, Chromium, Caesium, Copper, Gallium, Lead, Selenium, silver.

(a)

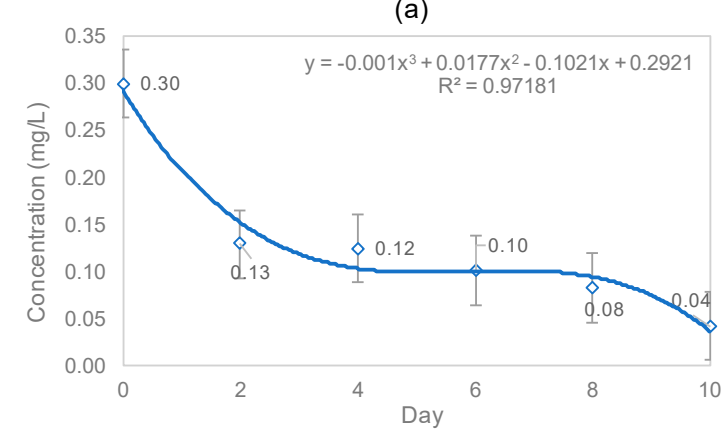

(c)

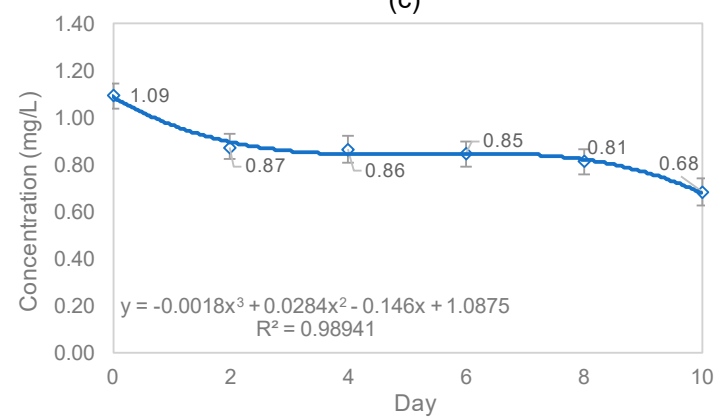

(b)

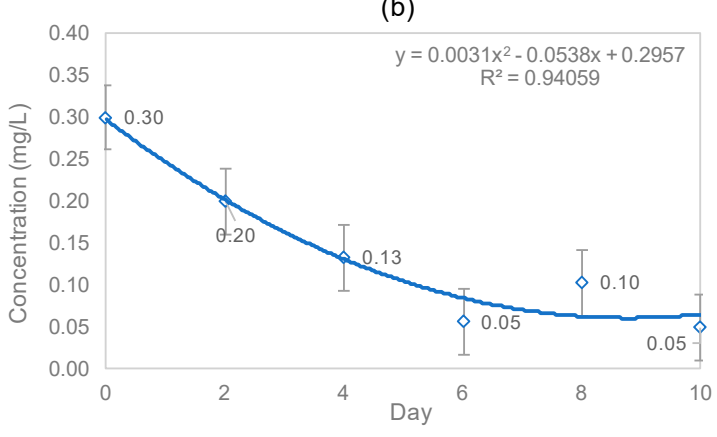

(d)

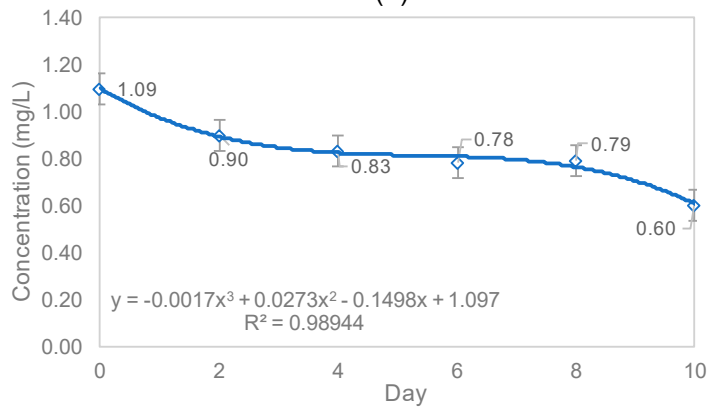

Figure 3. Reduction of: (a) Al concentration by Ipomoea aquatica; (b) Al concentration by Centella asiatica; (c) Fe concentration by Ipomoea aquatica; and (d) Fe concentration by Centella asiatica.

\subsubsection{Centella asiatica}

Figure 3 also shows readings for the $\mathrm{Al}$ content accumulated by $\mathrm{C}$. asiatica for 10 days of treatment. Readings recorded on day $0,2,4,6,8$, and 10 were $\sim 0.30,0.20,0.13,0.0,0.10$, and $0.05 \mathrm{mg} / \mathrm{L}$, respectively. 
On the final day of treatment, the heavy-metal concentration decreased by $83 \%$. A significant drop was recorded on the second day of treatment, which was $\sim 33 \%$. Figure 3 also shows readings for the Fe content for 10 days of treatment. Readings recorded on day $0,2,4,6,8$, and 10 were $\sim 1.09,0.90,0.83$, $0.78,0.79$, and $0.60 \mathrm{mg} / \mathrm{L}$, respectively. The heavy-metal concentration decreased by $45 \%$ on the final day of treatment. A significant drop was recorded on the second day of treatment, which was $\sim 17 \%$.

The present study found evidence of the ability of C. asiatica and I. aquatica as phytoremediation plants for removing $\mathrm{Al}$ and $\mathrm{Fe}$. These results were in good agreement with those reported previously, indicative of the ability of $C$. asiatica and I. aquatica for removing various pollutants. C. asiatica and I. aquatica were assessed in previous studies for its ability to remove various pollutants and water quality parameters, e.g., chemical oxygen demand (COD), biochemical oxygen demand (BOD), and ammoniacal nitrogen $\left(\mathrm{NH}_{3}-\mathrm{N}\right)$ [34], cadmium [35], lead [36], nitrate [37], total suspended solid (TSS) [38,39], copper [40], phosphate [41,42], nitrogen and phosphorus [43], and chromium (VI) [44]. Based on the previous studies, C. asiatica was found to be more efficient to remove most of the pollutants compared to I. aquatica. By comparing the efficiency rate of $C$. asiatica and I. aquatica obtained from the present study, a similar pattern of results was found in Ismail et al. [3] that have identified $S$. grossus as a hyperaccumulator in the phytoremediation of $\mathrm{Al}$ and $\mathrm{Fe}$. It should be noted that, however, the removal percentage rate of pollutants varies depending on the type of wastewater, duration of treatment, concentration of pollutant, etc.

\subsubsection{Amount of Heavy Metals in Leaves, Stems, and Roots}

Figure 4 presents the amount of heavy metals according to the treatment period for the leaf, stem, and root sections. The average Al content accumulated by I. aquatica was $\sim 1054 \mathrm{mg} / \mathrm{kg}$ per day, while the average Fe content was $972 \mathrm{mg} / \mathrm{kg}$ per day. The average contents of $\mathrm{Al}$ and Fe of C. asiatica were less than those ( $767 \mathrm{mg} / \mathrm{kg}$ per day and $\sim 47 \mathrm{mg} / \mathrm{kg}$ per day, respectively) of I. aquatica.

(a)

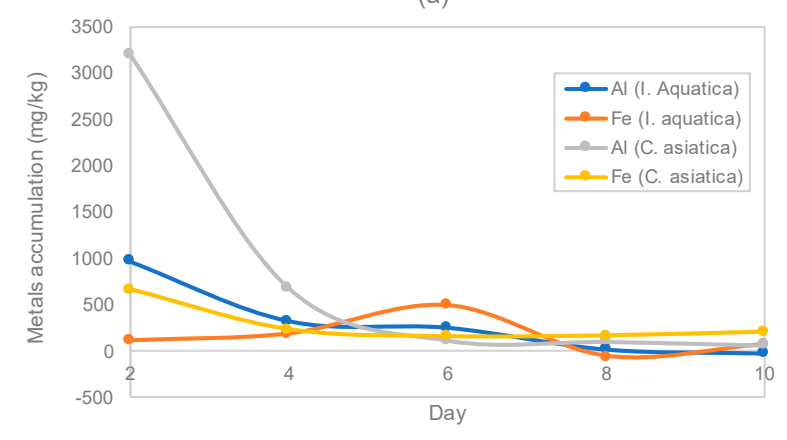

(b)

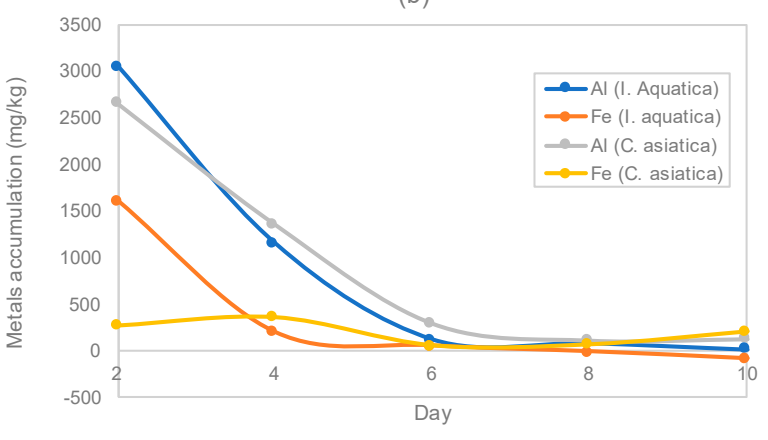

(c)

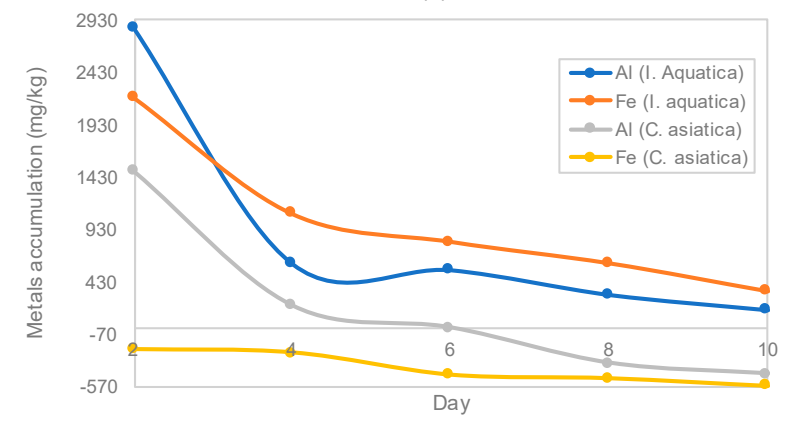

Figure 4. Accumulation of $\mathrm{Al}$ and $\mathrm{Fe}$ in the: (a) leaf; (b) stem, and (c) root sections by Ipomoea aquatica and Centella asiatica. 


\section{(a) Ipomoea aquatica}

Figure 4 shows the contents of $\mathrm{Al}$ in the leaf, stem, and root sections for day 2 to 10 of treatment by I. aquatica. Readings recorded for the leaf section were $973,332,261,27$, and $-15 \mathrm{mg} / \mathrm{kg}$. Overall, $\sim 1577 \mathrm{mg} / \mathrm{kg}$ of heavy metals was accumulated at 10 days of treatment, with an average of $157 \mathrm{mg} / \mathrm{kg}$ per day. The highest amount of heavy metals was recorded on the second day of treatment, which was $\sim 62 \%$. On the final day of treatment, the percentage of heavy metals in leaves was the lowest, which was $0.01 \%$ of the total amount of heavy metals.

The contents of heavy metals recorded for the stem section were $3055,1157,130,88$, and $18 \mathrm{mg} / \mathrm{kg}$. In total, $4447 \mathrm{mg} / \mathrm{kg}$ of heavy metals was recorded for day 2 to 10 of treatment, with an average content of $448 \mathrm{mg} / \mathrm{kg}$ per day. The highest amount of heavy metals was recorded on the second day, which was $\sim 69 \%$ of the total amount of heavy metals, while the percentage of heavy metals was the lowest on the final day, which was $0.01 \%$. The contents of heavy metals in the root section were 2859, $614,556,321$, and $175 \mathrm{mg} / \mathrm{kg}$. About $4524 \mathrm{mg} / \mathrm{kg}$ of heavy metals was recorded for 10 days of treatment, with an average amount of $\sim 452 \mathrm{mg} / \mathrm{kg}$ per day. The highest heavy metal content was recorded on the second day, which was $\sim 49 \%$. On the final day of treatment, the percentage of heavy metals in leaves was the lowest, which was $0.08 \%$ of the total amount of heavy metals.

Figure 4 also shows the contents of Fe in the leaf, stem, and root sections for day 2 to 10 of treatment. The contents of heavy metals accumulated in leaves were $113,190,499,-56$, and $75 \mathrm{mg} / \mathrm{kg}$. Overall, $\sim 821 \mathrm{mg} / \mathrm{kg}$ of heavy metals was accumulated at 10 days of treatment, with an average of $82 \mathrm{mg} / \mathrm{kg}$ per day. The highest content of heavy metals was recorded on the sixth day, which was $\sim 61 \%$ of the total amount of heavy metals, while the percentage of heavy metals was the lowest on the eighth day, which was $0.07 \%$. The contents of the heavy metals accumulated in the stem section were 1606, $197,55,-9$, and $-83 \mathrm{mg} / \mathrm{kg}$. About $1767 \mathrm{mg} / \mathrm{kg}$ of heavy metals was recorded for 10 days of treatment, with an average amount of $\sim 177 \mathrm{mg} / \mathrm{kg}$ per day. The highest content of heavy metals was recorded on the second day, which was $\sim 91 \%$. On the final day of treatment, the percentage of heavy metals in leaves was the lowest, which was $0.05 \%$ of the total amount of heavy metals. Readings recorded for the root section were 2198, 1089, 824, 621, and $352 \mathrm{mg} / \mathrm{kg}$. Overall, $\sim 5084 \mathrm{mg} / \mathrm{kg}$ of heavy metals was accumulated at 10 days of treatment, with an average of $508 \mathrm{mg} / \mathrm{kg}$ per day. The highest content of heavy metals was recorded on the second day, which was $\sim 43 \%$. On the final day of treatment, the percentage of heavy metals in leaves was the lowest, which was $0.07 \%$ of the total amount of heavy metals.

\section{(b) Centella asiatica}

Figure 4 shows the contents of $\mathrm{Al}$ in the leaf, stem, and root sections for day 2 to 10 of treatment by C. asiatica. Readings recorded for the leaf section were 3205, 690, 125, 111, and $72 \mathrm{mg} / \mathrm{kg}$. In total, $\sim 4202 \mathrm{mg} / \mathrm{kg}$ of heavy metals was accumulated at 10 days of treatment, with an average of $420 \mathrm{mg} / \mathrm{kg}$ per day. The highest content of heavy metals was recorded on the second day, which was $\sim 76 \%$. On day 10 , the percentage of heavy metals in leaves was the lowest, which was $0.02 \%$ of the total amount of heavy metals.

The contents of heavy metals recorded for the stem section were $2661,1364,303,122$, and $138 \mathrm{mg} / \mathrm{kg}$. About $4588 \mathrm{mg} / \mathrm{kg}$ of heavy metals was recorded for 10 days of treatment, with an average amount of $459 \mathrm{mg} / \mathrm{kg}$ per day. The highest content of heavy metals was recorded on the second day, which was $\sim 58 \%$ of the total amount of heavy metals, while the percentage of heavy metals was the lowest on the eighth day, which was $0.03 \%$. The contents of heavy metals in the root section were $1497,210,2,-338$, and $-440 \mathrm{mg} / \mathrm{kg}$. About $931 \mathrm{mg} / \mathrm{kg}$ of heavy metals was recorded for 10 days of treatment, with an average amount of $93 \mathrm{mg} / \mathrm{kg}$ per day. The highest content of heavy metals was recorded on the second day, which was $>160 \%$. On the final day of treatment, the percentage of heavy metals in leaves was the lowest, which was $47 \%$ of the total amount of heavy metals.

Figure 4 also shows the contents of Fe in the leaf, stem, and roots sections for day 2 to 10 of treatment. The contents of heavy metals accumulated in leaves were 667, 242, 169, 177, and $217 \mathrm{mg} / \mathrm{kg}$. 
About $1472 \mathrm{mg} / \mathrm{kg}$ of heavy metals was accumulated at 10 days of treatment, with an average of $147 \mathrm{mg} / \mathrm{kg}$ per day. The highest amount of heavy metals was recorded on the second day of treatment, which was $45 \%$ of the total amount of heavy metals, while the percentage of heavy metals was the lowest on the sixth day, which was $11 \%$. The contents of heavy metals accumulated in the stem section were $268,357,55,65$, and $204 \mathrm{mg} / \mathrm{kg}$. At 10 days of treatment, $948 \mathrm{mg} / \mathrm{kg}$ of heavy metals was recorded, with an average amount of $\sim 95 \mathrm{mg} / \mathrm{kg}$ per day. The highest amount of heavy metals was recorded on the fourth day, which was $38 \%$. On the sixth day of treatment, the percentage of heavy metals in leaves was the lowest, which was $0.06 \%$ of the total amount of heavy metals. Readings recorded for the root section were $-214,-245,-451,-484$, and $-557 \mathrm{mg} / \mathrm{kg}$. Overall, $1950 \mathrm{mg} / \mathrm{kg}$ of heavy metals was accumulated at 10 days of treatment, with an average of $195 \mathrm{mg} / \mathrm{kg}$ per day. The highest amount of heavy metals was recorded on the 10th day, which was $\sim 29 \%$, while on the second day of treatment, the percentage of heavy metals in leaves was the lowest, which was $11 \%$ of the total amount of heavy metals.

\subsubsection{Translocation Factor of Heavy Metals}

Table 2 shows the TF of aluminum and iron, reflecting the ability of I. aquatica to extract heavy metals from roots to shoots. Results revealed that TF $<1$ for I. aquatica, indicating that heavy metals are accumulated in the roots. For $\mathrm{Al}$ accumulation, the highest $\mathrm{TF}$ was observed on the fourth day of treatment, which was 0.54 , and the lowest TF was observed on the final day of treatment, which was 0.09. For Fe accumulation, the highest TF of 0.61 was observed on the sixth day of treatment, and the lowest TF of 0.09 was observed on the eighth day.

Table 2. Translocation factor for Ipomoea aquatica and Centella asiatica from root to leave (R/L).

\begin{tabular}{lcccccc}
\hline \multicolumn{7}{c}{ Translocation Factor/Day (TF) } \\
\hline \multicolumn{7}{c}{ Ipomoea aquatica } \\
\hline Day & 2 & 4 & 6 & 8 & 10 & MIN \\
Aluminum & 0.34 & 0.54 & 0.47 & 0.08 & $(0.09)$ & 0.27 \\
Iron & 0.05 & 0.17 & 0.61 & 0.09 & 0.21 & 0.19 \\
\hline \multicolumn{7}{c}{ Centella asiatica } \\
\hline Day & 2 & 4 & 6 & 8 & 10 & MIN \\
Aluminum & 2.14 & 3.28 & 54.94 & 0.33 & 0.16 & 11.97 \\
Iron & 3.11 & 0.99 & 0.38 & 0.37 & 0.39 & 1.05 \\
\hline
\end{tabular}

Table 2 also shows the TF of aluminum and iron, reflecting the ability of C. asiatica to extract heavy metals from roots to shoots. Results indicated for $\mathrm{Al}$, TF $>1$, and the highest TF of 55 is observed on the sixth day of treatment. The lowest TF of 0.16 was observed on the 10th day of treatment. For Fe accumulation, $\mathrm{TF}<1$ was observed for $C$. asiatica, implying that heavy metals are accumulated in the roots or other parts of the plant. The highest TF of 3.11 was observed on the second day of treatment, and the lowest TF of 0.37 was observed on the eighth day.

The results showed that there were significant differences in iron translocation factors in the stems by Ipomoea aquatica compared to leaves. For Centella asiatica, a significant value was obtained for the amount of iron in the leaves and stems. For aluminum, Ipomoea aquatica recorded a significant value for metal translocation from roots to leaves and from roots to stems. However, no significant value was recorded for the aluminum by Centella asiatica.

Basically, most of the heavy metals accumulate in plant roots because the surface area of root hairs is greater than those of stems and leaves for the absorption of heavy metals [14]. Besides, roots are the first part of a plant that absorb heavy metals from soil or a waterbody before their distribution to the other parts. In addition, compared to stems and leaves, roots are the only covered part, and they are in contact with the growth medium. Hence, roots demonstrate more potential to absorb nutrients and pollutants due to their plant physiology. 
Ismail et al. [3] found that the Scirpus grossus accumulated $\mathrm{Al}$ and Fe from mining wastewater, implying the potential of Scirpus grossus as a hyperaccumulator in the phytoremediation of $\mathrm{Al}$ and $\mathrm{Fe}$. Syabani et al. [44] have reported bioconcentration factor (BCF) $<1$ for $C$. asiatica. However, TF $>1$ was observed for the accumulation of $\mathrm{Pb}, \mathrm{Cu}$, and $\mathrm{Zn}$, indicating that even though $\mathrm{C}$. asiatica is not a potential hyper accumulator or a phytostabilization agent, this species is tolerant to $\mathrm{Pb}, \mathrm{Cu}$, and $\mathrm{Zn}$. $\mathrm{A}$ $\mathrm{BCF}$ range from 0.01 to 0.10 for $\mathrm{Zn}$ and $\mathrm{Pb}$ revealed that $C$. asiatica is a weak accumulator for these metals. Based on the study conducted by Yoon et al. [45], the highest ratio of lead (Pb) concentration reflects the accumulation from roots to stems, while the lowest ratio reflects accumulation from roots to leaves. The study determined the concentrations of $\mathrm{Pb}$ and $\mathrm{Cd}$ accumulated in I. aquatica at Laguna de Bay Filipina. Results indicated that the $\mathrm{Pb}$ concentration of the plant section follows the order of roots $\geq$ vertical stems $\geq$ horizontal stems $\geq$ leaves. The ratio is 0.82 stems/roots and 0.36 leaves/roots.

A graph of the heavy-metal concentration $(\mathrm{mg} / \mathrm{L})$ over treatment days revealed that the regression (R2) value is positive and close to $\mathrm{R} 2$ of $1: \mathrm{R} 2$ for $\mathrm{Al}$ is 0.7607 , and $\mathrm{R} 2$ for $\mathrm{Fe}$ is 0.8239 for I. aquatica, and $\mathrm{R} 2$ for $\mathrm{Al}$ is 0.8182 and $\mathrm{R} 2$ for $\mathrm{Fe}$ is 0.8862 for C. asiatica. This result indicated that the heavy-metal concentration exhibits a good relationship for reflecting the decrease in the heavy-metal concentration over the treatment day. If the regression was similar to $\mathrm{R} 2=1$, it verified the relationship between the variables and vice versa, if $\mathrm{R} 2<1$.

In addition, the TF of roots to stems was calculated to determine the location of heavy metal accumulation as an alternative for the accumulation of heavy metals from roots to leaves. Table 3 summarizes the TF of aluminum and iron, reflecting the ability of I. aquatica to extract heavy metals from roots to stems. The results indicated that $\mathrm{TF}<1$ for I. aquatica, indicating that most of the heavy metals are still accumulated in the roots. For $\mathrm{Al}$ accumulation, the highest $\mathrm{TF}$ was observed on the second day of treatment, which was 1.89, while the lowest TF was observed on the final day, which was 0.10 . For Fe accumulation, the highest TF was observed on the second day of treatment, which was 0.73 , and the lowest TF was observed on the eighth day, which was 0.01 .

Table 3. Translocation factor for Ipomoea aquatica and Centella asiatica from root to stem (R/S).

\begin{tabular}{lcccccc}
\hline \multicolumn{7}{c}{ Translocation Factor/Day (TF) } \\
\hline \multicolumn{7}{c}{ Ipomoea aquatica } \\
\hline Day & 2 & 4 & 6 & 8 & 10 & MIN \\
Aluminum & 1.07 & 1.89 & 0.23 & 0.27 & 0.10 & 0.71 \\
Iron & 0.73 & 0.18 & 0.07 & -0.01 & -0.23 & 0.15 \\
\hline \multicolumn{7}{c}{ Centella asiatica } \\
\hline Day & 2 & 4 & 6 & 8 & 10 & MIN \\
Aluminum & 1.78 & 6.48 & 133.20 & $(0.36)$ & $(0.31)$ & 28.16 \\
Iron & $(1.25)$ & $(1.46)$ & $(0.12)$ & $(0.13)$ & $(0.37)$ & $(0.67)$ \\
\hline
\end{tabular}

Table 3 also shows the TF of aluminum and iron, reflecting the ability of $C$. asiatica to extract heavy metals from roots to stems. Results indicated that TF $>1$ for $\mathrm{Al}$ accumulation, and the highest TF is observed on the sixth day of treatment, which is 133 . The lowest TF was obtained on the final day, which was 0.31 . For Fe accumulation, $\mathrm{TF}<1$, and it is negative, indicating that most of the heavy metals are not accumulated in the roots due to the amount of heavy metals in the roots was negative.

Results obtained for the TF of heavy metals via their accumulation in leaves and stems by $I$. aquatica revealed that a significant TF variation is observed for the stem section compared to the leaf section. For $\mathrm{Al}$ accumulation, I. aquatica exhibited significant TF of heavy metals from roots to leaves $(\mathrm{R} / \mathrm{L})$ and from roots to stems $(\mathrm{R} / \mathrm{S})$, while for $C$. asiatica, a significant value was obtained for the amount of Fe in leaves and stems. No significant value for $\mathrm{Al}$ accumulation was observed, even though $\mathrm{TF}$ for stems $(\mathrm{TF}=132)$ and leaves $(\mathrm{TF}=54)$ was different. 


\section{Conclusions}

In this study, Ipomoea aquatica and Centella asiatica were selected as phytoremediation plants based on their rapid growth rate and lower maintenance costs. Results revealed that I. aquatica exhibits higher $\mathrm{Al}$ content than $\mathrm{C}$. asiatica. It was also found that the average content of Fe accumulated by I. aquatica was greater than that accumulated by C. asiatica. Besides, with respect to the wastewater treatment by I. aquatica, a significant variation between the TF of $\mathrm{Fe}$ in the stem compared to the leaf section was observed, indicating that most of the Fe accumulate in stems. For C. asiatica, TF $<1$ for Fe in leaves and stems, and it was negative, indicating that heavy metals are not accumulated in roots because the amount of heavy metals in the roots was negative. TF $>1$ for $\mathrm{Al}$ accumulated in leaves and stems of both plant species, indicating that both plants can accumulate and extract heavy metals from wastewater.

Author Contributions: Formal analysis, M.F.Z..; writing—original draft preparation, M.F.Z. and M.M.H.; writing-review and editing, A.A.H., M.M.H. and N.U.M.N. and A.R.; supervision, M.M.H.; funding acquisition, M.M.H. All authors have read and agreed to the published version of the manuscript.

Funding: This research was funded by the UKM research grants (DIP-2019-001 and MI-2020-005).

Acknowledgments: This study was financed by the research grants (DIP-2019-001; KRA-2018-054; and MI-2020-005).

Conflicts of Interest: The authors declare no conflict of interest.

\section{References}

1. Ashraf, M.A.; Hanafiah, M.M. Sustaining life on earth system through clean air, pure water, and fertile soil. Environ. Sci. Pollut. Res. 2019, 26, 13679-13680. [CrossRef] [PubMed]

2. Hanafiah, M.M.; Yussof, M.K.M.; Hasan, M.; AbdulHasan, M.J.; Toriman, M.E. Water quality assessment of Tekala River, Selangor, Malaysia. Appl. Ecol. Environ. Res. 2018, 16, 5157-5174. [CrossRef]

3. Ismail, N.I.; Abdullah, S.R.S.; Idris, M.; Abu Hasan, H.; Halmi, M.I.E.; Al Sbani, N.H.; Jehawi, O.H. Simultaneous bioaccumulation and translocation of iron and aluminium from mining wastewater by Scirpus grossus. Desalin. Water Treat. 2019, 163, 133-142. [CrossRef]

4. Hanafiah, M.M.; Mohamad, N.H.S.M.; Aziz, N.I.H.A. Salvinia molesta dan Pistia stratiotes sebagai agen fitoremediasi dalam rawatan air sisa kumbahan. Sains Malays. 2018, 47, 1625-1634. [CrossRef]

5. Morais, S.; Costa, F.G.E.; Pereira, M.D.L. Heavy Metals and Human Health. In Environmental Health: Emerging Issues and Practice; IntechOpen: Rijeka, Croatia, 2012; pp. 227-246.

6. Shuhaimi-Othman, M.; Ahmad, A.; Mushrifah, I.; Lim, E.C. Seasonal influence on water quality and heavy metals concentration in Tasik Chini, Peninsular Malaysia. In Proceedings of the 2007: The 12th World Lake Conference, Jaipur, India, 28 October-2 November 2007; pp. 300-303.

7. Ariffin, F.D.; Halim, A.A.; Hanafiah, M.M.; Ramlee, N.A. Kebolehupayaan fitoremediasi oleh Azolla pinnata dalam merawat air sisa akuakultur. Sains Malays. 2019, 42, 281-289. [CrossRef]

8. Bakar, A.F.A.; Halim, A.A.; Hanafiah, M.M. Optimization of coagulation-flocculation process for automotive wastewater treatment using response surface methodology. Nat. Environ. Pollut. Tech. 2015, 14, 567-572.

9. Gupta, V.K.; Suhas. Application of low-cost adsorbents for dye removal-A review. J. Environ. Manag. 2009, 90, 2313-2342. [CrossRef]

10. Bakar, A.F.A.; Barkawi, S.N.M.; Hanafiah, M.M.; Ern, L.K.; Halim, A.A. Heavy metals removal from automotive wastewater using chemically modified sand. Sains Malays. 2016, 45, 1509-1516.

11. Meagher, R.B. Phytoremediation of Toxic Elemental and Organic Pollutants. Curr. Opin. Plant Biol. 2000, 3, 153-162. [CrossRef]

12. Gisbert, C.; Ros, R.; De Haro, A.; Walker, D.J;; Bernal, M.P.; Serrano, R.; Navarro-Aviñó, J. A plant genetically modified that accumulates $\mathrm{Pb}$ is especially promising for phytoremediation. Biochem. Biophys. Res. Commun. 2003, 303, 440-445. [CrossRef]

13. James, J.T.; Dubery, I.A. Pentacyclic triterpenoids from the medicinal herb, Centella asiatica (L.). Molecules 2009, 14, 3922-3941. [CrossRef] [PubMed] 
14. Yap, C.K.; Fitri, M.R.; Mazyhar, Y.; Tan, S.G. Effects of Metal-contaminated Soils on the Accumulation of Heavy Metals in Different Parts of Centella asiatica: A Laboratory Study. Food Chem. Toxicol. 2010, 39, 347-352.

15. Ahmadpour, P.; Anmadpour, F.; Mahmud, T.M.M.; Abdu, A.; Soleimani, M.; Hesseini Tayefeh, F. Phytoremediation of heavy metals: A green technology. Afr. J. Biotechnol. 2012, 11, 14036-14043.

16. Favas, P.J.C.; Pratas, J.; Varun, M. Phytoremediation of Soils Contaminated with Metals and Metalloids at Mining Areas: Potential of Native Flora. In Environmental Risk Assessment of Soil Contamination; IntechOpen: Rijeka, Croatia, 2014; pp. 487-517.

17. Souza, L.A.; Piotto, F.A.; Nogueirol, R.C.; Azevedo, R.A. Use of non-hyperaccumulator plant species for the phytoextraction of heavy metals using chelating agents. Sci. Agric. 2013, 70, 290-295. [CrossRef]

18. Hanafiah, M.M.; Ghazali, N.F.; Harun, S.N.; Abdulaali, H.; AbdulHasan, M.J.; Kamarudin, M.K.A. Assessing water scarcity in Malaysia: A case study of rice production. Desalin. Water Treat. 2019, 149, $274-287$. [CrossRef]

19. Rahman, M.A.; Hasegawa, H. Aquatic Arsenic: Phytoremediation Using Floating Macrophytes. Chemosphere 2011, 83, 633-646. [CrossRef]

20. Rahman, M.M.; Tan, P.J.; Faruq, G.; Sofian, A.M.; Rosli, H.; Boyce, A.N. Use of Amaranth (Amaranthus paniculatus) and Indian Mustard (Brassica juncea) for Phytoextraction of Lead and Copper from Contaminated Soil. Int. J. Agric. Biol. 2013, 15, 903-908.

21. Karami, A.; Shamsuddin, Z.H. Phytoremediation of heavy metals with several efficiency enhancer methods. Afr. J. Biotechnol. 2010, 9, 3689-3698.

22. Majid, N.M.; Islam, M.M.; Nap, M.E.; Ghafoori, M.; Abdu, A. Heavy metal uptake and translocation by Justicia gendarussa Burm F. from textile sludge contaminated soil, Acta Agriculturae Scandinavica. Soil Plant Sci. 2012, 62, 101-108.

23. Ho, W.M.; Ang, L.H.; Lee, D.K. Assessment of Pb uptake, translocation and immobilization in kenaf (Hibiscus cannabinus L.) for phytoremediation of sand tailings. J. Environ. Sci. 2008, 20, 1341-1347. [CrossRef]

24. Choo, T.P.; Lee, C.K.; Low, K.S.; Hishamuddin, O. Accumulation of chromium (VI) from aqueous solutions using water lilies (Nymphaea spontanea). Chemosphere 2006, 62, 961-967. [CrossRef] [PubMed]

25. Syuhaida, A.W.A.; Norkhadijah, S.I.S.; Praveena, S.M.; Suriyani, A. The Comparison of Phytoremediation Abilities of Water Mimosa and Water Hyacinth. J. Sci. Technol. 2014, 4, 722-731.

26. Akinbile, C.O.; Yusoff, M.S. Assessing Water Hyacinth (Eichhornia crassopes) And Lettuce (Pistia stratiotes) Effectiveness. In Aquaculture Wastewater Treatment. Int. J. Phytore. 2012, 14, 201-211. [CrossRef] [PubMed]

27. Lim, S.L.; Chu, W.L.; Phang, S.M. Use of Chlorella vulgaris for bioremediation of textile wastewater. Bioresour. Technol. 2010, 101, 7314-7322. [CrossRef] [PubMed]

28. Ashraf, M.A.; Maah, M.J.; Yusoff, I. Assessment of phytoextraction efficiency of naturally grown plant species at the former tin mining catchment. Fresenius Environ. Bull. 2012, 21, 523-533.

29. Flora Zambesiaca, Kew Databases. Royal Botanical Gardens Kew; Richmond, VT, USA, 2014. Available online: http://apps.kew.org/efloras/fz/families.htm[10/12/2016] (accessed on 15 November 2019).

30. Hashim, P.; Sidek, H.; Helan, M.H.M.; Sabery, A.; Palanisamy, U.D.; Ilham, M. Triterpene composition and bioactivities of Centella asiatica. Molecules 2011, 16, 1310-1322. [CrossRef]

31. Ton, S.-S.; Lee, M.-W.; Yang, Y.-H.; Hoi, S.-K.; Cheng, W.-C.; Wang, K.-S.; Chang, H.-H. Effects of Reductants on Phytoextraction of Chromium (VI) Ipomoea aquatica. Int. J. Phytore. 2014, 17, 429-436. [CrossRef]

32. Ladislas, S.; Gérente, C.; Chazarenc, F.; Brisson, J.; Andrès, Y. Performances of Two Macrophytes Species in Floating Treatment Wetlands for Cadmium, Nickel, and Zinc Removal from Urban Stormwater Runoff. Water Air Soil Pollut. 2013, 224, 1408. [CrossRef]

33. Zhang, I.; Wong, M.H. Environmental mercury contamination in China: Sources and impacts. Environ. Int. 2007, 33, 108-121. [CrossRef]

34. Azarpira, H.; Behdarvand, P.; Dhumal, K.; Pondhe, G. Phytoremediation of Municipal Wastewater by Using Aquatic Plants. Adv. Environ. Biol. 2013, 7, 4649-4654.

35. Bhaduri, A.M.; Fulekar, M. Assessment of Arbuscular Mycorrhizal Fungi on the Phytoremediation Potential of Ipomoea aquatica on Cadmium Uptake. Biotech 2012, 2, 193-198. [CrossRef]

36. Chanu, L.B.; Gupta, A. Phytoremediation of Lead Using Ipomoea aquatica Forsk. In Hydroponic Solution. Chemosphere 2016, 156, 407-411. [CrossRef] [PubMed] 
37. Effendi, H.; Utomo, B.A.; Darmawangsa, G.M. Phytoremediation of Freshwater Crayfish (Cherax quadricarinatus) Culture Wastewater with Spinach (Ipomoea aquatica) in Aquaponic System. AACL Bioflux 2015, 8, 421-430.

38. Mahmud, H.; Lee, K.E.; Goh, T. On-Site Phytoremediation Applicability Assessment in Alur Ilmu, Universiti Kebangsaan Malaysia Based on Spatial and Pollution Removal Analyses. Environ. Sci. Pollut. 2017, 24, 22873-22884. [CrossRef] [PubMed]

39. Md Saat, S.K.; Qamaruz Zaman, N. Suitability of Ipomoea aquatica for the Treatment of Effluent from Palm Oil Mill. J. Built Environ. Technol. Eng. 2017, 2,39-44.

40. Mokhtar, H.; Morad, N.; Fizri, F.F.A. Phytoaccumulation of Copper from Aqueous Solutions using Eichhornia crassipes and Centella asiatica. Int. J. Environ. Sci. Dev. 2011, 2, 205. [CrossRef]

41. Nizam, N.U.M.; Hanafiah, M.M.; Noor, I.M.; Karim, H.I.A. Efficiency of five selected aquatic plants in phytoremediation of aquaculture wastewater. Appl. Sci. 2020, 10, 1-11.

42. Nuwansi, T.; Verma, A.; Rathore, G.; Prakash, C.; Chandrakant, M.H.; Prabhath, A. Utilization of Phytoremediated Aquaculture Wastewater for Production of Koi Carp (Cyprinus carpio Var. Koi) and Gotukola (Centella asiatica) in an Aquaponics. Aquacult 2019, 507, 361-369. [CrossRef]

43. Rane, N.R.; Patil, S.M.; Chandanshive, V.V.; Kadam, S.K.; Khandare, R.V.; Jadhav, J.P.; Govindwar, S.P. Ipomoea hederifolia Rooted Soil Bed and Ipomoea aquatica Rhizofiltration Coupled Phytoreactors for Efficient Treatment of Textile Wastewater. Water Res. 2016, 96,1-11. [CrossRef]

44. Syabani, M.; Nugraha, F.; Noordiyanto. Phytoremediation Potential of Ipomoea aquatica for Water Contaminated with Hexavalent Chromium (Potensi Phytoremediation Dari Ipomoea aquatica Untuk Air Terkontaminasi Kromium Valensi Enam). In Proceedings of the Prosiding Workshop Penelitian dan Pengembangan Kulit, Karet dan Plastik, Yogyakarta, Indonesia, 19 October 2011; pp. 1-13.

45. Yoon, J.; Cao, X.; Zhou, Q.; Ma, L.Q. Accumulation of $\mathrm{Pb}, \mathrm{Cu}$, and $\mathrm{Zn}$ in native plants growing on a contaminated Florida site. Sci. Total Environt. 2006, 368, 456464. [CrossRef] 